\title{
Evaluation of zirconia bonding to veneering porcelain
}

\author{
Aneta Mijoska $^{1 *}$, Mirjana Popovska \\ Faculty of Dentistry, St. Panteleimon P.H.O. Dental Clinical Centre, \\ ${ }^{I}$ Clinic of Prosthodontics, Faculty of Dentistry, ,, Ss Cyril and Methodius " University, \\ Vodnjanska 16, 1000 Skopje, Republic of Macedonia \\ ${ }^{2}$ Clinic of Oral pathology and Periodontology, Faculty of Dentistry, ,,Ss Cyril and Methodius “ University, \\ Vodnjanska 16, 1000 Skopje, Republic of Macedonia
}

Received: August 2014; Accepted: October 2014

\begin{abstract}
Zirconium dioxide as core ceramic material for dental crowns and bridges, possess high strength, chemical stability and superior aesthetics after veneering. Veneering ceramic is considered to be the weakest part of all-ceramic restorations. The adhesion between the core and veneering porcelain is based on the manner in which the connection occurs in metal-ceramic structures. Standard procedures for connecting zirconia to hard dental tissues and veneering materials do not achieve the required strength of bonding.

The aim of the paper is to investigate different surface treatments of the zirconium dioxide ceramic core and find the best, for achieving highest adhesive bonding values to veneering porcelain. The study was primarily designed to investigate the bonding strength of the veneering porcelain to zirconia with in vitro Macro shear bond strength test. The specimens with different surface treatment of the zirconia were divided in five groups of twelve according to the treatment of zirconium surface and results showed highest bonding values for specimens treated with Rocatec system.
\end{abstract}

Key words: surface treatment, zirconia, bonding, adhesion, shear bond, veneering porcelain

\section{Introduction}

The need for higher biocompatibility and better dental aesthetics led to development of all-ceramic prosthodontic systems which are increasingly applied, although their clinical performances and success are not yet proofed (Aboushelib et al., 2005). All-ceramic dental restorations have ceramic core instead of metal alloy and veneering ceramic porcelain in their composition (Guazzato et. al., 2004)

Zirconium dioxide as core ceramic material for dental crowns and bridges, possess high strength, chemical stability and white color with opportunity for superior aesthetics after veneering (Anusavice, 2003). The finer granulation of ceramic powder and tetragonal-monocyclic transformation plays important role in the strength of zirconium as material for all-ceramic substructure. Veneering porcelain for zirconia dioxide ceramics possess the same strength as the materials for veneering of the metal core, but clinical practice showed that the prosthetic structures made of veneered zirconia often damaged and fractured in the mouth (Fischer et al., 2008). Damage occurs during the mastication processes as shearing off the fragments of porcelain mass and serious fractures of the zirconium base (Stawarczyk et al., 2011). Veneering ceramic is considered to be the weakest part of all-ceramic restorations and several factors influence, such as: thermal expansion mismatch, overload

\footnotetext{
*amijoska@yahoo.com
} 
at the premature contacts, ceramic strength and its adhesive bonding abilities (Estevam et al., 2010).

Different thermal expansion coefficients (CTE) of the bonded materials play important role in forming residual stress in the materials $\left(\mathrm{O}^{\prime \prime} \mathrm{zcan}, 2003\right)$. The stress which is formed during cooling process of the ceramic is so called "transient" stress, while the stress which occurs at the room temperature after cooling is called "residual stress". Both stresses can be compressive or tensile, and if we know that porcelain is not tolerant to tensile stress, it should be set at lower compressive stress (Gostemeyer et.al., 2010). This means that the substructure core material must be with higher contraction than porcelain during cooling process (Sui et al, 2013). In ideal cases the difference between two materials CTE should be less than $10 \%$, but there is no ideal thermal cycle for metal-ceramic and all-ceramic restorations (Mainjot et al., 2012). Some degree of compatibility is possible due to the expansion coefficients of the two materials, porcelain firing temperature, the resistance of the core at high temperature, the release of internal stress of the core and ceramic, the thickness ratio of the two materials and the adhesive bond between them (Kelly et al., 1990).

Mechanisms for bonding zirconia to veneering porcelain are not sufficiently clarified, but it is known that the strength of the adhesion in all-ceramic system is weaker than the one in metal-ceramic systems (Aksoy et al., 2006). The adhesion between the core and veneering porcelain is based on the manner in which the connection occurs in metal-ceramic structures (Motoaki et al., 2011).

Zirconia is the solid material with inactive surface, resistant to most classical methods of bonding. Standard procedures for connecting to hard dental tissues and veneering materials do not achieve the required strength of bonding (Farga-Niñoles et al., 2013). Zirconia is basically metal and its connection with porcelain is chemical, while the residual thermal stress occurring during cooling has a great influence on the strength of the connection (Aboushelib et al., 2009).

The strength of the zirconia-porcelain bonding depends on several factors, as follows: zirconia surface, residual thermal stress, CTE, defects in materials, defects at the bonding interface, "wetting" and ceramic strength (Kosmač et al., 2008). Process of "wetting" actually represents the creation of an intimate contact between the two elements without the formation of cavities, and is very important when applying adhesive structures.

Great strength and density of sintered zirconia and the lack of glassy matrix make it resistant to most conventional surface treatments. Unlike silicate feltsphatic porcelain whose surface properly treated and roughened accomplishes good bonding, unreactive surface of zirconia is an issue due to poor adhesion with other elements (Shimizu et al., 1993). Examination in which the relationship is examined by SEM showed that there is a mutual diffusion of $\mathrm{Zr}$ and $\mathrm{Si}$ of $\mathrm{SiO}_{2}$ from porcelain, presented on Fig.1. This phenomenon explains the effects of adhesion and bonding strength between both ceramics and adhesives fractures along connected part, suggesting that the relationship between porcelain and zirconia can be classified as "strong" (Song et al., 2013).

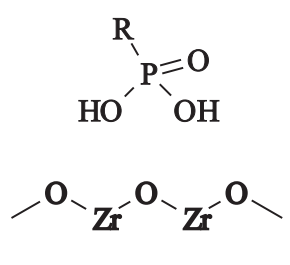

Zirconia

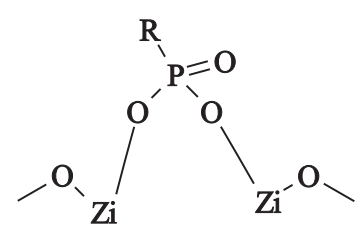

Zirconia
Fig. 1 Cohesive adhesion with oxide materials- chemical chelation with hydrogen bonds.

Several different surface treatment are suggested for improvement of the bonding procedures, such as: mechanical surface roughening, tribochemistry and silanisation, application of the liners, thermal spray, fusion with glassy balls, chloro-silane treatment with steam, selective infiltration etching which creates inter-granular porosity, complex phosphate primer that react with hydroxyl groups, corrosion with hot solutions, laser treatments (Nd: YAG, $\mathrm{CO}_{2}$ ) and others (Sato et al., 2008; Al-Wahadni and Martin, 1998).

The aim of the study was to investigate different surface treatments of the zirconium dioxide ceramic and find the best, for achieving highest adhesive bonding values.

\section{Material and methods}

\section{Materials}

Sixty square-shaped specimens $(6 \mathrm{~mm} \times 10 \mathrm{~mm} \times$ $10 \mathrm{~mm}$ ) were made of zirconium dioxide ceramic blocks (DeguDent Cercon base 47, Dentsply International Inc, Hanau-Wolfgang, Germany), cut with diamond saw and then sintered in the oven (Cercon heat) at $1350{ }^{\circ} \mathrm{C}$ for 6 hours. Afterwards the samples were placed in an acrylic polymer material to form the bonding substrate for veneering porcelain stubs. The veneering ceramic (Cercon Ceram kiss, Degudent, Hanau, Germany) was built up to the final dimension (thickness of $3 \mathrm{~mm}$ ) according to the firing program of the manufacturer as seen on Fig. 2.

The specimens with different surface treatment of the zirconia were divided in five groups of twelve:

1. Group A are control group without treatmentspecimens were cleaned in an ultrasonic bath and porcelain was sintered in the oven according manufacturer;

2. Group A1 are specimens cleaned in an ultrasonic bath and treated with SiC-discs (P220, P500 and P1200 according ISO 6344-1: 1998); 


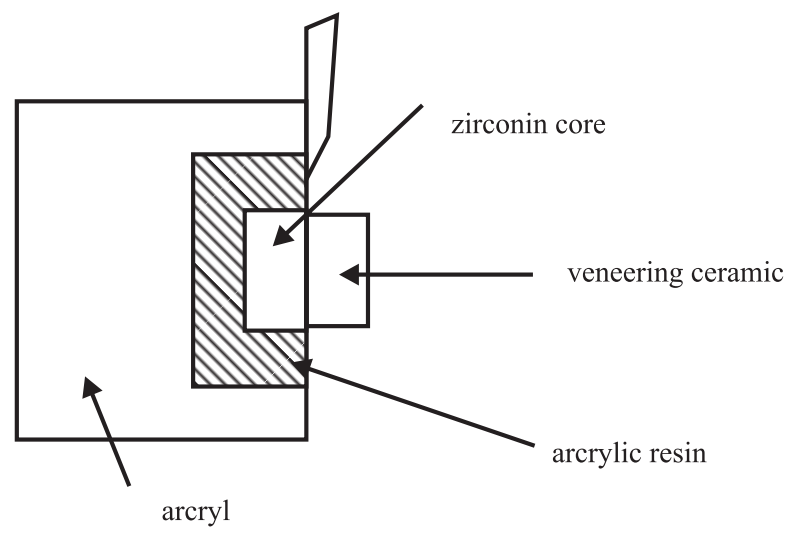

Fig. 2 Schematic view of the shear bond strength test.

3. Group $\mathrm{A} 2$ are specimens with surface treatmentair particle abrasion with alumina oxide $\left(\mathrm{Al}_{2} \mathrm{O}_{3}\right)$ with diameter of $110 \mu \mathrm{m}$ for 15 seconds with a sand blasting device at air pressure 15 bars, at the $10 \mathrm{~mm}$ distance from zirconia surface;

4. Group A3 are specimens with surface treatment - liner (Cercon Ceram Kiss Liner, Degudent Hanau, Germany) applied with brush on ultrasonically cleaned zirconia surface in thin layer and sintered according to the manufacturer.

5. Group A4 are specimens with surface treatment - tribochemical air abrasion with Rocatec system (3M ESPE, USA) and silane primer. Rocatec plus silica powder was used for air particle abrasion for 15 seconds with a sand blasting device at air pressure 2,8 bars, at the 10 $\mathrm{mm}$ distance from zirconia surface.

\section{Testing design}

The present study was primarily designed to investigate the bonding strength of the veneering porcelain to zirconia with in vitro Macro shear bond strength test. The experiment had been done with universal testing machine Shimadzu Autograph AGS-X in the Laboratory for calibration of the force and moment of the force at the Faculty for Mechanical Engineering in Skopje according to standards (ISO 29022: 2013 Dentistry-AdhesionNotched- edge shear bond strength Test). This test has special bonding matrices in which the specimens are laid and notched-edged blade on cross-head is cutting the bonding interface as presented in Fig. 3.

Each specimen from every group was mounted in the testing jig and force was applied to the specimens, so that shear load directly adjacent the bonding interface as seen on Fig. 4. The cross-head was moving down the notched-edge blade with speed of $0,75 \pm 0,30 \mathrm{~mm} / \mathrm{min}$. The cutting edge was in position as close as possible to the bonding surfaces at the distance of about $0,5 \mathrm{~mm}$ to prevent movement from the loading. Testing machine was connected with computer software during the testing and automatically displayed load failure force in $\mathrm{N}$ (Newtons).

\section{Calculation of the shear bond strength}

The average shear bond strength was calculated with formula:

$$
\text { Shear stress }(\mathrm{MPa})=\operatorname{Load}(\mathrm{N}) / \operatorname{Area}\left(\mathrm{mm}^{2}\right) \text {, }
$$

where load $(\mathrm{N})$ is applied shear force and area is bonded

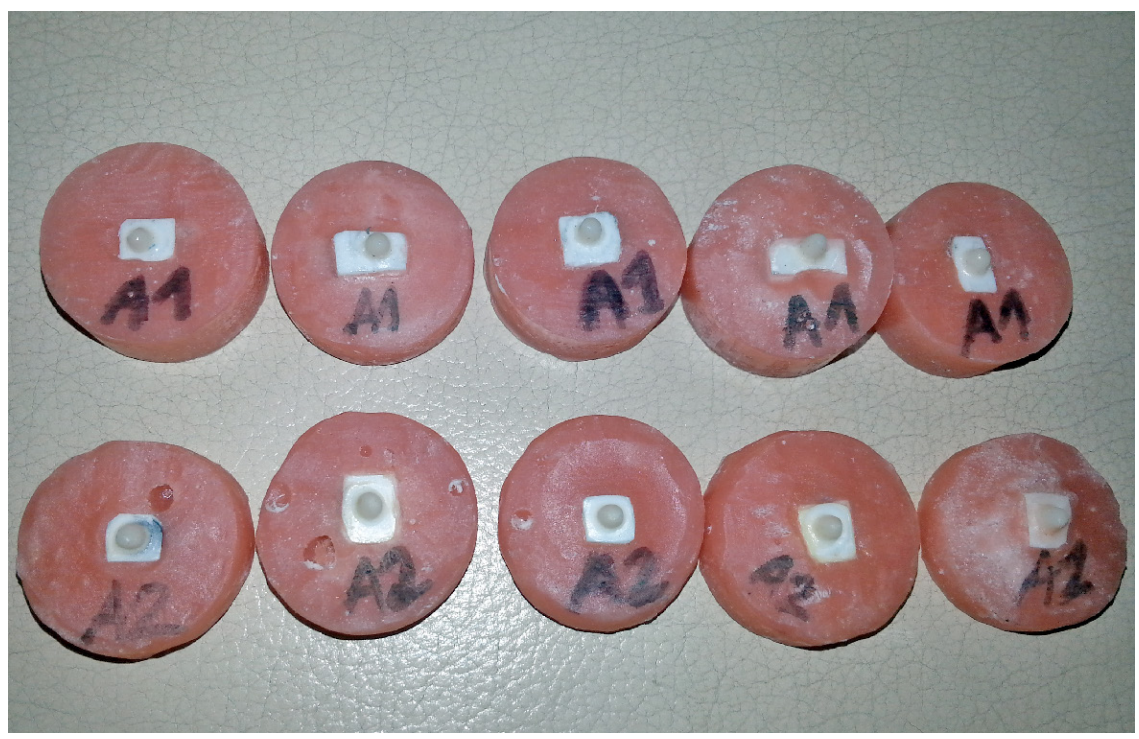

Fig. 3. Zirconia veneered specimens in acrylic molds. 
interface area $\left(\mathrm{mm}^{2}\right)$. Fracture of the veneering porcelain could be easily seen, and the fracture surface and type were examined and classified in three different groups: Adhesive - failure at the connection between ceramic and porcelain; Cohesive - failure inside the porcelain and Combined mix of the previous.

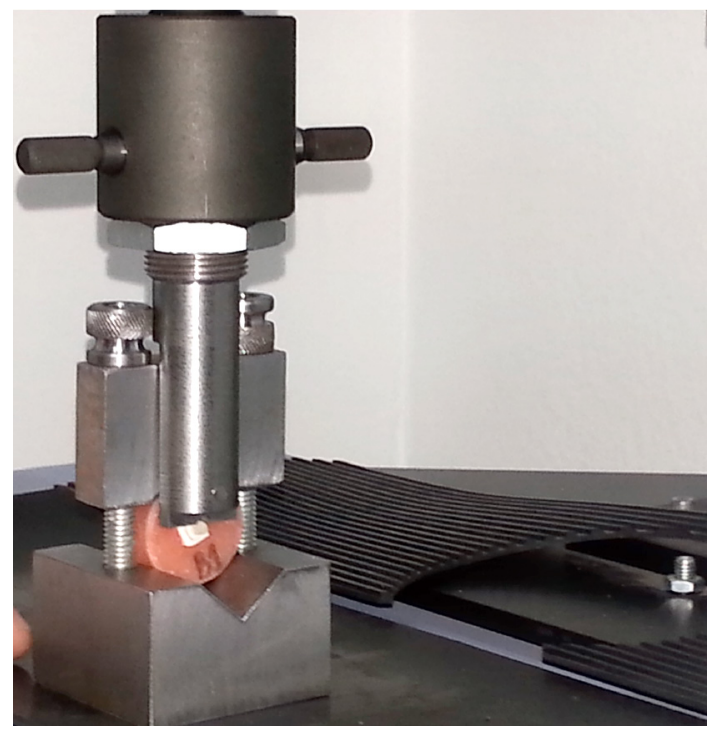

Fig. 4. Shear bond notched edge test with specimen in the bonding clamp.

\section{Results}

The statistical analysis was carried out and the results showed significant differences for the shear bond strength between measured data in all tested groups of specimens at the significant level of 0,05 . Group A4 showed highest values of the shear stress, group A2 and A1 showed similar values, while lowest value of the shear stress showed group A3, and the results are presented on Table 1.

Broken specimens were examined under the SEM (scanning electronic microscope) and most of them showed mixed cohesive/adhesive failures and very small amount of porcelain mass left attached to the zirconia surface. Specimens from group A3 showed fracture surfaces covered with liner or veneer material.

\section{Discussion}

Bonding means connecting and establishing stable adhesive contact between two materials. There are several different theories about the adhesion between base metal and veneering porcelain in metal-ceramic restorations. Primary connection is chemical, mechanical, adhesive, Van der Waals's forces, compression and interzonal material (Dündar et al., 2007). According to ISO standards metalceramic restorations should possess minimum $25 \mathrm{MPa}$ bonding strength, and several different studies showed values ranging 54-71 Mpa (Scherrer et al., 2010). There is not standard value for zirconia-veneering porcelain bonding strength, but the results of our investigation showed high bonding values with all different surface treatments.

Brittle all-ceramic restorations don't have standardized test for measuring of the bond strength, as metal-ceramic. Different testing methods had been used such as macro and micro shear bond strength test, three-point, four-point bending tests and micro-tensile test (Van Meerbeek et al., 2010). They all have certain disadvantages, but shear bond strength (SBS) test is used in this study because of easy preparation of the specimens and simple test protocol (Sadighpour et al., 2006). High standard deviations, influence from the shape and stress force are its main disadvantages. Very important thing for the examination is providing stabile and strong fixation and connection between zirconia and acrylic resin. Adjusting of the acrylic base with grinding can cause some damage to the bonded area, experience and skill of the operator is also very important (Scherrer et al., 2009). Fabrications of the specimens is very important because initial fractures that lead to failure may start from present pores and defects, surface polishing etc. However in order to minimize technical mistakes one person did the fabrication of the specimens and testing experiment. Most of the in vitro tests are static and held in dry environment which lead to faster delamination of the material (Betamar et al., 2007)

Zirconia surface is very compact and inert to most convenient treatment, but some materials for improving of the bonding are used in the experiment. They are different liners like paste applied on the surface in thin layer after activating with sandblasting (Isgro et al., 2003). Liners are material that should ensure physical bond and compensate inadequate CTE. They are products similar to opaque, and they can provide surface roughness, modify shade

Table1. Mean shear bond strength values for different surface treatments

\begin{tabular}{ccc}
\hline \hline Specimen group & Surface treatment & $\begin{array}{c}\text { Shear bond strength values } \\
\text { Mpa }\end{array}$ \\
\hline A & Without treatment & $30,03 \pm 5,70$ \\
A1 & Treated with sic-discs & $21,30 \pm 4,02$ \\
A2 & Air Particle Abrasion $\left(\mathrm{Al}_{2} \mathrm{O}_{3}\right) / 110 \mu \mathrm{m}$ & $26,30 \pm 2,50$ \\
A3 & Liner & $20,30 \pm 6,30$ \\
A4 & Rocatec system & $34,21 \pm 5,49$ \\
\hline
\end{tabular}


and improve bonding to the porcelain. Surface abrasion or roughening (grinding, airborneparticle abrasion, rotary abrasion using diamond burs) establishes adhesion with micro-mechanical retention. There is a general consensus that airborne particle abrasion with 50-110 $\mu \mathrm{m}$ alumina particles at $0.25 \mathrm{MPa}$ is effective in roughening and cleaning the bonding surface of zirconia. However, the effect of those treatments on the mechanical properties of Y-TZP materials is controversial and both positive and negative results have been described in the literature (Sato et al., 2008). Zirconium dioxide ceramic used in the study is material where manufacturer recommend surface treatments, if done correctly according to their instructions.

Treatment with Rocatec system (3M ESPE, USA) for silanization forms chemical bonding due to application of the mechanical energy, and the procedure is in three stages (cleaning, blasting and silanization). Blasting of the surface was made with aluminum oxide particle size 110 $\mu \mathrm{m}$ modified with silica $(\mathrm{SiO} 2)$ and it was covered with silane liquid ethanol solution ES PE Sil (3M ESPE, USA) afterwards. Particles of the silicon oxide penetrate $15 \mu \mathrm{m}$ and fuse to the surface. Silane solution has two molecules at the edges with different polarity and alchoxy group on the left side (RO) 3Si- allows chemical bonding on the surface. Our investigation showed that this treatment although quite expensive and complicated, can improve bonding between zirconia and veneering ceramic.

\section{Conclusion}

With the limitation of this in vitro study next conclusion were drawn:

1. There were significant differences in the shear bond strength values for all different groups of specimens;

2. Group A3 (treatment with liner) showed lowest value of the shear bond strength;

3. Group A4 (treatment with Rocatec) showed highest value of the shear bond strength;

4. Surface analysis showed that fracture originated from the porcelain, and thin layer of porcelain and liner remained on zirconia surface.

5. There must be effort to improve strength properties of the veneering ceramics for zirconium pointed towards increasing of the bonding strength between two materials

The main dilemma still remains over whether it is necessary or not to do the sanding of the surface, and how any treatment is going to impact on the strength and stability of the core material during the years of exploitation.

\section{References}

Aboushelib, MN., de Jager, N., Kleverlaan, CJ., Feilzer, AJ., 2005. Micro tensile bond strength of different components of core veneered all-ceramic restorations. Dent Mater. 21, 984-991.

Aboushelib, M.N., Ghoniem, M, Mirmohammadi, H., Salameh, Z., 2009.General principles for achieving adequate bond to all-ceramic restorations. Journal of Dentistry and Oral Hygiene. 1(3), 36-41.

Aksoy, G., Polat, H., Polat, M., Coskun, G., 2006. Effect of various treatment and glazing (coating) techniques on the roughness and wettability of ceramic dental restorative surfaces. Colloids Surf B Biointerfaces. 53, 254-259.

Al-Wahadni, A., Martin, D., 1998. Glazing and finishing dental porcelain: a literature review. J Can Dent Assoc. 64, 580583.

Anusavice, K.J., 2003. Mechanical properties of dental materials. 'Phillips' science of dental materials'. 93(11), 521-530.

Betamar, N., Cardew, G., Van Noort, R., 2007. Influence of specimen designs on the microtensile bond strength to dentin. J Adhes Dent .9, (22) 159-68

Dündar, M., Özcan, M., Gökçe, B., Çömlekoğlu, E., Leite, F., Valandro, L.F., 2007. Comparison of two bond strength testing methodologies for bilayered all-ceramics. Dental Materials. 23, 630-636.

Estevam, A., Bonfante, A., Paulo, G., Coelho, B., Petra, C., Guess, C., Van, P., Thompson, B., Nelson, R., Silva, D., 2010. Fatigue and damage accumulation of veneer porcelain pressed on Y-TZP. Journal of dentistry. 38, $318-324$.

Farga-Niñoles, I., Agustín-Panadero, R., Román-Rodriguez, J.L., Solá-Ruíz, M.F., Granell-Ruíz, M., Fons-Font, A., 2013. Fractographic study of the behavior of different ceramic veneers on full coverage crowns in relation to supporting core materials. J Clin Exp Dent. 5 (5), 260-6.

Fischer, J., Stawarczyk, B., Hammerle, CHF., 2008. Flexural strength of veneering ceramics for zirconia. Journal of dentistry. 36 (5), $316-321$.

Gostemeyer, G., Jendras, M., Dittmer, M.P., Bach, F.W., Stiesch, M., Kohorst, P., 2010. Influence of cooling rate on zirconia/ veneer interfacial adhesion. Acta Biomater 6,4532-8.

Guazzato, M., Albakry, M., Ringer, S.P., Swain, M.V., 2004. Strength, fracture toughness and microstructure of a selection of all-ceramic materials. Part II. Zirconia-based dental ceramics. Dental Materials 20(5), 449-456.

Isgro, G., Pallav, P., van der Zel, J.M., Feilzer, A.J., 2003. The influence of the veneering porcelain and different surface treatments on the biaxial flexural strength of a heat-pressed ceramic. The Journal of Prosthetic Dentistry. 90, 465-473.

Kosmač, T., Oblak, Č., Marion, L., 2008. The effects of dental grinding and sandblasting on ageing and fatigue behavior of dental zirconia (Y-TZP) ceramics. J Eur Ceram Soc. 28, 1085-1090.

Kelly, R., Giordano, R., Pober, R., Cima, MJ., 1990. Fracture surface analysis of dental ceramics: clinically failed restorations. Int J Prosthodont. 3, 430-436.

Mainjot, A.K., Schajer, G., Vanheusdena, A.J., Sadoun, M.J., 2012. Influence of veneer thickness on residual stress profile in veneering ceramic: Measurement by hole-drilling. Dental materials. 28, 160-167.

Motoaki, I., J. Raigrodski, A., Flinn, B.D., Chung, K.H., Spiekerman, Ch., Winters, RR., 2011. Shear bond strengths of pressed and layered veneering ceramics to high-noble alloy 
and zirconia cores. The Journal of Prosthetic Dentistry.106, $29-37$.

Özcan, M., 2003. Fracture reasons in ceramic-fused-to-metal restorations. Journal of Oral Rehabilitation. 30, 265-269.

Sadighpour, L., Geramipanah, F., Raeesi, B., 2006. In Vitro Mechanical Tests for Modern Dental Ceramics. Journal of Dentistry. 3 (3), 143-152.

Sato, H., Yamada, K., Pezzotti, G., Nawa, M., Ban, S., 2008. Mechanical properties of dental zirconia ceramics changed with sandblasting and heat treatment. Dent Mater J. 27, 408-414.

Scherrer, S., Cesar, PF., Swain, MS., 2010. Direct comparison of the bond strength results of the different test methods: A critical literature review. Dental Materials. 26(2), 78-93.

Shimizu, K., Oka, M., Kumar, P., Kotoura, Y., Yamamuro, T., Makinouchi, K., Nakamura, T.,1993. Time-dependent changes in the mechanical properties of zirconia ceramic. $\mathrm{J}$ Biomed Mater Res A. 27, 729-734.
Song, J.Y., Won Park, S., Lee, K., Yun, K.D., Lim, H.P.,2013. Fracture strength and microstructure of Y-TZP zirconia after different surface treatments. Journal of Prosthetic Dentistry. 110(4), 274-280

Stawarczyk, B., Özcan, M., Roos, M., Trottmann, A., Hämmerle. C.H.F., 2011. Fracture load and failure analysis of zirconia single crowns veneered with pressed and layered ceramics after chewing simulation. Dental Materials Journal. 30(4), 554-562.

Sui, T., Dragnevski, K., Neo, T.K., M. Korsunsky, A., 2013. Mechanisms of failure in porcelain-veneered sintered zirconia restorations. 13th International Conference on Fracture. Beijing, China.

Van Meerbeek, B., Peumans, V., Poitevin, A., Mine, A., Van Ende, A., Neves, A., Munck, J.D., 2010. Relationship between bond-strength tests and clinical outcomes, Dent Mater J. 26,100-121.

\title{
Евалуација на поврзувањето на цирконијата со порцеланските маси за фасетирање
}

\author{
Анета Мијоска ${ }^{1 *}$, Мирјана Поповска ${ }^{2}$

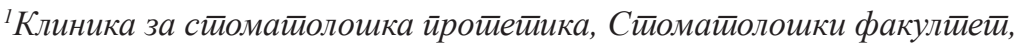 \\ Универзитетет ,Св. Кирил и Метиояиј“, 1000 Скойје

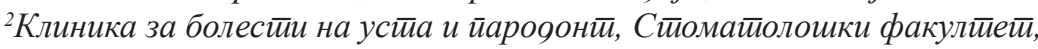 \\ Универзитетет „Св. Кирил и Метовоиј “, Скойје
}

Клучни зборови: површински третман, цирконија, бондирање, атхезија, смолкнување, фасетен поцелан

Циркониум диоксид како материјал за основа на денталните коронки и мостови, поседува голема сила, хемиска стабилност и супериорна естетика после фасетирањето. Фасетната керамика пак се смета за најслабиот дел од целосно керамичките реставрации. Поврзувањето помеѓу основата и фасетниот порцелан се базира на поврзувањето кое се јавува и кај метал-керамичките конструкции. Стандардните процедури на поврзување на цирконијата со тврдите забни ткива и фасетните материјали не ја даваат потребната сила на бондирање.

Целта на студијата е да се истражат различни површински третмани на цирконијата за да се одредат оние со кои се постигнуваат највисоки вредности на поврзувањето. Студијата ги испитува силите на поврзувањето на фасетниот порцелан и цирконијата со Макро тестот на силата на смолкнување. Примероците беа поделени во пет групи по дванаесет, според различниот површински третман, а резултатите добиени после тестирањето покажаа највисоки вредности на силата на поврзување кај примероците третирани со Рокатек системот. 